\title{
The Meaning and Function of Naga Raksasa (Giant Dragon) Myth in Hutabolon, Parbaba Village, Samosir Regency, Indonesia
}

\author{
Agung Suharyanto ${ }^{1}$, Wiflihani ${ }^{2}$, Armansyah Matondang ${ }^{3}$, Heri Kusmanto ${ }^{4}$ \\ \{agungsuharyanto@staff.uma.ac.id ${ }^{1}$, wiflihani@unimed.ac.id ${ }^{2}$, armansyahmatondang@staff.uma.ac.id \\ , herikusmanto@usu.ac.id ${ }^{4}$ \} \\ ${ }^{1}$ Government Science Study Program, Faculty of Social and Political Sciences, Universitas Medan Area, \\ Indonesia \\ ${ }^{2}$ Department of Music Education, Faculty of Languages and Arts, Universitas Negeri Medan, Indonesia. \\ ${ }^{3}$ Communication Studies Program, Faculty of Social and Political Sciences, Universitas Medan Area, \\ Indonesia \\ ${ }^{4}$ Political Science Department, Faculty of Social and Political Sciences, Universitas Sumatera Utara, \\ Indonesia
}

\begin{abstract}
The purpose of this study is to find out the functions and meanings in the daily lives of Hutabolon towards the Naga Raksasa (giant dragon) myth that is believed to be the incarnation of ancestors who preserve the natural preservation of Lake Toba. To achieve this goal, this study uses descriptive approach research with research informances namely indigenous people who live in Hutabolon, Parbaba Village, Panguruan Subdistrict, Samosir Regency, by conducting field observations and conducting unstructured interviews by interviewing key informants because they are considered know the problems that researchers are careful about. The results of the study show that the Naga Raksasa (giant dragon) myth is not an alien thing and is considered to have a function and meaning that is closely related to the daily lives of its people. In terms of his beliefs, as a guardian and protector of the community and told to every visitor and posterity, in order to continue to maintain the attitude around Lake Toba.
\end{abstract}

Keywords: function; meaning; perseption; behavior; Naga Raksasa (Giant Dragon) myth; lake toba.

\section{Introduction}

Indonesia is a country that is very rich in cultural diversity. This is because Indonesia consists of various ethnic groups where each ethnic group has differences and uniqueness both in terms of regional languages, customs, and various other things that enrich the diversity of Indonesian culture itself. As Taylor's opinion [1] culture is the whole of knowledge, beliefs, art, morals, laws, customs, abilities and other habits acquired by someone. The era of globalization is a development of knowledge and technology that occurs in the world including Indonesia. In the current era of globalization, mastery of technology becomes a prestige and an indicator of a country's progress. The state is said to be advanced if it has a 
high technology level, while countries that cannot adapt to technological advances are often referred to as failed countries [2].

One sign of the development of science in Indonesia is that many Indonesians are now able to achieve a high level of education and are supported by better technology, this makes many Indonesians think rationally based on science. The knowledge of the community resulted in people thinking more logically about something and more trusting to go to the police station when they lost something than a shaman or paranormal. This situation shows that culture is not a fixed thing but something that changes. Culture is as attitude and belief, ways of thinking, behaving, and remembering together by the members [3]. Cultural change is the process of shifting, reducing, adding and developing elements in a culture. In simple terms, cultural change is a dynamic that occurs due to collisions between different cultural elements [4].

Cultural changes in society can be characterized by logical thinking that can change beliefs in society in their daily lives. But there is still a lot of public trust regarding the myths of higher power, which encourages people in the modern era to believe in the magical powers that exist in their surroundings, one of which is that many people believe in sacred places and supernatural beings who dwells on the face of the earth. The myths that are believed in the midst of society at this time is something very interesting to study which is still often found in a particular region or region. Because of the many elements of society who still believe in a myth that is considered very influential in everyday life in society.

Various myths that develop among the people around Lake Toba. These myths are still alive and developing in Hutabolon, Parbaba Village, Samosir Regency. These myths include myths about Naga Raksasa (giant dragon) that are in the Lake Toba of Hutabolon, Parbaba village. Since ancient times, Samosir Regency is very well known by the community as a volcanic island in the middle of Lake Toba. Its height is 1,000 meters above sea level. This is what makes Lake Toba a concern for domestic and foreign tourists [5]. The myth of the Naga Raksasa (giant dragon) is a story that developed in Hutabolon area of Parbaba Village, where in this myth involves a giant dragon who is a guardian of the community around Lake Toba. Although this myth is passed down orally for years, the myth is not lost and is still believed in modern times.

The Hutabolon community in Parbaba Village still believes in the existence of a Naga Raksasa (giant dragon) myth that lives inside Lake Toba which is responsible for protecting the ecosystem of the surrounding area as a manifestation of ancestors. As informed, that there is a grandfather and teenagers in coastal Lake Toba see a giant dragon swim calmly in the waters of Lake Toba. Village elders also say, the giant dragon is thousands of years old, male sex. The color is yellowish green, along with more than half the length of the Lake Toba, and the width of more than a quarter of the lake [6].

Every society who believes in the existence of a Naga Raksasa is of the opinion that the giant dragon is the guardian of Lake Toba which is entrusted by ancestors thousands of years ago. So when crossing Lake Toba is required to maintain the attitude and cooperation if not then the Lake Toba will sink the ship that is not obedient to the rules set by ancestors hundreds of years ago. But there are still many different views of the community about the existence of the Naga Raksasa figure, some argue that the Naga Raksasa is frightening when moving and will endanger the people who live on the coast of Lake Toba, if the Naga Raksasa moves then the Naga Raksasa will shake all the surface of Lake Toba. As a result of the shock that is too powerful, able to sink the ships that were sailing.

\section{Research Methods}


This research was conducted in Hutabolon, Parba Village, Panguruan District, Samosir Regency, North Sumatra, Indonesia. This type of research was qualitative research. Qualitative data according to Sugiyono was data in the form of sentences, words, or images. The term qualitative research was intended as a type of research whose findings prioritize processes and were not obtained through statistical procedures or other forms of calculation [7].

To achieve this goal, this study used a descriptive approach research method with informants, namely indigenous people who live there. This research conducted direct observations in the field and conducted $g$ interviews directly with informants. Briefly the author had made a summary, namely through the process of collecting data obtained from both interviews, observations, and from other literature. Next the researcher conducted groupings of answers that refer to the focus of the research that had been predetermined, the presentation of data was adjusted to the formulation of the problem in this study. Then the researcher drawn conclusions which were taken of course based on an understanding of the data that had been presented and made in a brief statement and easily understood by referring to the subject matter under study.

\section{Results and Discussion}

\subsection{Naga Raksasa (giant dragon) myth in Hutabolon, Parbaba Village, Samosir Regency}

Folklore is an English word. The word is a compound word, which comes from two basic words namely folk and lore. According to Alan Dundes, folk is a group of people who have physical, social, and cultural identifying characteristics, so that they can be distinguished from other groups. Identifying features include tangibility: the same skin color, the same hair shape, the same livelihood, the same language, the same level of education, and the same religion. But even more important is that they have a tradition, a culture that they have inherited from generation to generation which is at least two generations, which they can recognize as common property. Besides that, the most important thing is that they are aware of the identity of their own group [8].

According to Jan Harold Brurivand, folklore is a part of the culture of a collective, which is spread and passed down from generation to generation, among any kind of collective, traditionally in different versions, both in oral form and example accompanied by gestures or reminder aids (mnemonic device) [9].

Myth is part of the grouping of forms of folklore, oral folklore. In the distribution of verbal folklore, there are 6 divisions, one of which is the story of people's prose. According to William R. Bascom, the story of people's prose is divided into three major groups, namely: (1) myth, (2) legend (folkstory), and (3) folktale [10] This myth of the giant dragon is included in the form of folk prose which is a division of oral folklore. The Naga Raksasa (giant dragon) myth is a concept from the myth itself that originates from oral folklore. The difference between the two is in its own meaning, namely 1) myths have something to be revealed while, 2) legend as something that is considered really happening.

Naga Raksasa (giant dragon) myth is a story that developed in Hutabolon area of Parbaba Village, where in this myth involves a Naga Raksasa (giant dragon) who is a guardian of the community around Lake Toba. The community still believes in the myth of a giant dragon inhabiting the lake of Toba. Even now the KM Sinar Bangun inauguration in mid-June also circulated the story of the dragon guarding the lake. Residents and elders around believe the dragon figure as the embodiment of Samosir, the Toba child who survived when the village 
sank, and now there are still many people who cross Lake Toba must maintain their attitudes and ways of speaking.

3.2 Community Perception of Naga Raksasa (Giant Dragon) Myth in Lake Toba in Hutabolon Neighborhood of Parbaba Village, Samosir Regency

The people in the settlements around the village of Parbaba strongly believe in the existence of Naga Raksasa (giant dragon) in the vicinity of Lake Toba and even many people who believe the sinking of KM Sinar Bangun and many boats that sink when crossing the Lake Toba are caused by angry Naga Raksasa (giant dragon) at the bottom of Lake Toba, because the ships that cross do not comply with the existing rules. For the people of Parbaba Village, Naga Raksasa (giant dragon) myth is not a foreign matter and is even attached to the daily lives of its people. For the people of Parbaba Village, Naga Raksasa (giant dragon) myth is not foreign and even sticky with the daily lives of the people.

Understanding the perception of the psychological dictionary is derived from English, perception which means: perception, vision, response; is the process of a person becoming aware of everything in his environment through his senses; or environmental knowledge obtained through the interpretation of sensory data [11]. Factors that influence perception are internal factors: feelings, experience, thinking ability, motivation and frame of reference. While external factors are: the stimulus itself and the state of the environment in which the perception takes place [12] [13]. Based on the results of interviews with the local community that the social groups of the Parbaba community have confidence in the giant dragon myths based on social groups. First is people's perceptions seen in terms of age, research shows that the Parbaba people who believe in the giant dragon myth are old people and citizens native to the village of Parbaba. The second is the public perception seen from gender, namely the Parbaba Society still believes in the giant dragon myth, both men and women. This is according to the statement from Ibu Hutabarat, who is one of the resource persons of the researcher who lives in the village of Parbaba.

Third is public perception seen from the education level. In this case the results of the study show that the people of Parbaba who believe in Naga Raksasa (giant dragon) myth are usually high school graduates. The results of observations by researchers are still many people who are in the neighborhood around the village of Parbaba who have not tasted education to university. So that there are still many people who have not thought rationally about an event that occurred in the environment around them. Fourth, the public perception seen in terms of types of work are people who have jobs as fishermen who are always in the coastal area of Lake Toba. Many fishermen are of the opinion that when they cast nets to catch fish sometimes they get scales like snake scales and very large size and people think that it is Naga Raksasa (giant dragon) scales that reside at the bottom of Lake Toba.

\subsection{Functions and Meanings of Naga Raksasa (Giant Dragon) Myth in the Surrounding Community}

According to Bascom, myth or myth is a folk prose story, which is considered truly happening and is considered sacred by the owner of the story [14]. According to Malinowski myth is a sacred story that is almost always present in every culture in any society [15]. In accordance with the results of the study, it was found that Naga Raksasa (giant dragon) myth was seen from the belief factor, the community believed the giant dragon myth until now because the community considered that the Naga Raksasa (giant dragon) myth because of the ancestors who were useful for the security of humanity. In the village of Parbaba, the 
dominant community is very confident that Naga Raksasa (giant dragon) myth inside Lake Toba is a guardian who acts as a protector.

According to the results of the study, it was concluded that Naga Raksasa (giant dragon) myth was seen from socio-cultural factors, many people still believe in the existence of Naga Raksasa (giant dragon) myth in Hutabolon neighborhood of Parbaba village because it had become a culture for the people of Parbaba and its surroundings. To every visitor and their children and grandchildren to continue to maintain the attitude around Lake Toba.

The existence of Naga Raksasa (giant dragon) myth is very influential on the activities of the people who are around Lake Toba today. Where each visitor arrives around the village of Parbaba, many people give input not to behave strangely and seem negative in the coastal area of Lake Toba especially when crossing Lake Toba. From the amount of advice given by the people around the village of Parbaba, many visitors to the village of Parbaba always maintain their way of speaking and they are always careful in doing things, so that they arrive at their destination safely.

\section{Conclusion}

For the people of Parbaba Village, now they still believe in Naga Raksasa (giant dragon) myth which is at the bottom of Lake Toba. This perception can be seen in terms of age, which is an elderly community and is a native of the village of Parbaba. Seen from gender, the Parbaba Society still believes in Naga Raksasa (giant dragon) myth, both men and women. Viewed from the level of education, it shows that the people of Parbaba who believe in Naga Raksasa (giant dragon) myth are usually high school graduates who have not tasted education until college, so there are still many people who have not thought rationally about an event that occurred around them. In terms of type of work, people who have jobs as fishermen are always in the coastal area of Lake Toba. The functions and meanings of the myths shape people's attitudes and behavior as individual efforts to maintain the natural environment around Lake Toba. In other words, when there is an individual who damages or pollutes the surrounding environment, then the individual will get reprimand in the form of seeing and feeling large animals near them. This is the impact of community behavior that does not preserve the natural preservation and cleanliness of Lake Toba.

\section{References}

[1] Horton, P.B \& Chester L.H. Sosiologi. Jakarta: Erlangga (1993).

[2] Ngafifi, M. Kemajuan Teknologi Dan Pola Hidup Manusia Dalam Perspektif Sosial Budaya. Wonosobo: Jurnal Pembangunan Pendidikan: Fondasi dan Aplikasi (2014).

[3] Pengertian dan Definisi Kebudayaan Menurut Para Ahli. Dalam http://carapedia.com/pengertian_definisi_kebudayaan_menurut_para_ahli_info495.htm 1. diakses pada 8 April 2019

[4] Koentjaraningrat. Pengantar Ilmu Antropologi. Jakarta: Rineka Cipta. (2009). https://nasional.kompas.com/amp/read/2011/10/15/03150215/TOBA.MENGUBAH.D UNIA

[5] https://toplintas.com/naga-raksasa-muncul-di-danau toba/https://samosirkab.go.id/geograf

[6] Sugiyono. Metodelogi Penelitian Kuantitatif, Kualitatif Dan R\&D. Bandung: ALFABETA (2013)

[7] Danandjaja, J. Folklor Indonesia, Ilmu Gosip, Dongeng dan lan-lain. Jakarta: Grafik Press. pp. 1 (1997) 
[8] Danandjaja, J. Folklor Indonesia, Ilmu Gosip, Dongeng dan lan-lain. Jakarta: Grafik Press. pp. 2 (1997)

[9] Danandjaja, J. Folklor Indonesia, Ilmu Gosip, Dongeng dan lan-lain. Jakarta: Grafik Press. pp.50-51 (1997)

[11] Adrianto, B. Persepsi dan Partisipasi Masyarakat terhadap Pembangunan Prasarana Dasar Pemukiman yang Bertumpu pada Swadaya Masyarkat di Kota Magelang. Tesis. Semarang.undip (2006).

[12] Kusmanto, H. Persepsi Masyarakat Terhadap Upaya Kepala Kelurahan Sebagai Salah Satu Unsur Pelaksana Pemerintahan Kota Medan, Jurnal Ilmu Pemerintahan dan Sosial Politik, 3 (1): pp. $49-57$ (2015).

[13] Siregar, N.S.S. Persepsi Orang Tua terhadap Pentingnya Pendidikan bagi Anak, Jurnal Ilmu Pemerintahan dan Sosial Politik, 1 (1): 11-27. (2013).

[14] Danandjaja, J. Folklor Indonesia, Ilmu Gosip, Dongeng dan lan-lain. Jakarta: Grafik Press. Pp.50-51 (1997)

[15] Malinowski, B. The Dynamics of Cultural Change; an Inquiry into Racerelations in Africa. New Haven: Yale University Press, pp. 17 (1955) 